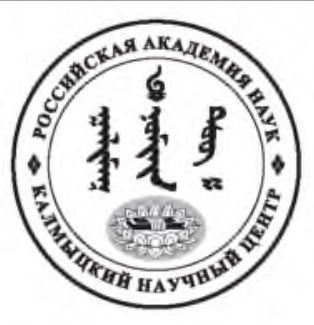

Published in the Russian Federation

Oriental Studies (Previous Name: Bulletin of the Kalmyk Institute

for Humanities of the Russian Academy of Sciences)

Has been issued as a journal since 2008

ISSN: 2619-0990; E-ISSN: 2619-1008

Vol. 14, Is. 2, pp. 238-247, 2021

Journal homepage: https://kigiran.elpub.ru

УДК / UDC 947 (470)

DOI: $10.22162 / 2619-0990-2021-54-2-238-247$

\title{
Попытки Кучумовичей и башкир воссоздать Сибирское ханство
}

\author{
Aзаm Caлаватович Caльманов
}

${ }^{1}$ Институт истории, языка и литературы Уфимского федерального исследовательского центра РАН (д. 71, проспект Октябряя, 451145 Уфа, Российская Федерация)

кандидат исторических наук. научный сотрудник

(D) 0000-0003-4410-5392. E-mail: azat-salmanovía mail.ru

\author{
(C) КалмНЦ РАН, 2021 \\ (C) Сальмнов А. С., 2021
}

Аннотация. Введение. В конце XVI в., как принято считать в отечественной историографии, произошло крушение Сибирского ханства. Однако долгое время после этого события бывшие владетели Сибирского юрта Кучумовичи (дети и внуки сибирского хана Кучума) неоднократно пытались вернуть свою власть. В достижении своей цели они опирались на башкирских и калмыцких лидеров. Идейными сторонниками потомков Кучума являлись сибирские татары и башкиры, в первую очередь башкирские табынцы. которые также желали восстановить Сибирское ханство. Однако в исторической науке остается без внимания вопрос участия башкир в деле Кучумовичей вернуть себе Сибирский юрт. Цель исследования - изучение этнополитической истории зауральских башкир XVII в. в призме движения Кучумовичей, калмыков и джунгар, выступавших с идеей возвращения Сибирского ханства. Mamepиаль и методы. В своей работе автор опирается на известные в научной среде материалы, которые, однако, не рассматривались в призме участия башкир в обшем движении кочевых лидеров в борьбе за восстановление Сибирского ханства. В целом. с использованием методов исторического исследования (исторического, сравнительного и системного), это дало возможность установить, что на территории Башкирии действия башкирских повстанцев были связаны с политикой Кучумовичей и калмыцких тайшей, пытавшихся объединить башкир и жителей Западной Сибири для выхода из подчинения московскому правительству. Таким образом, научная новизна заключается в том, что впервые рассматривается антироссийское движение башкир XVII в. в контексте попыток восстановления Сибирского ханства. В резулыmame анализа исторических событий (уход внука Кучума Кучука к каракалпакам и принятие калмыцким владетелем Аюкой российского подданства) становится очевидным, что в среде восстававших башкир произошло крушение надежд на воссоздание Сибирского ханства как на возможность обретения независимости от Русского государства. Bыєводы. Башкирские восстания второй половины XVII в. следует рассматривать в русле политической ситуации, сложившейся на юго-восточной окраине России из-за совместных активных действий Кучумовичей, калмыцких и башкирских предводителей. 
Ключевые слова: башкиры, калмыки, Кучумовичи, Сибирское ханство, Башкирия, Южное Зауралье, этнополитическая история

Благодарность. Исследование проведено в рамках государственной субсидии - проект «Духовная культура тюркских народов Южного Урала» (номер госрегистрации: AAAA-A17-117040350082-3).

Для цитирования: Сальманов А. С. Попытки Кучумовичей и башкир воссоздать Сибирское ханство // Oriental Studies. 2021. Т. 14. № 2. С. 238-247. DOI: 10.22162/2619-0990-2021-54-2$238-247$

\title{
Kuchum's Descendants and the Bashkirs: Attempts of Reconstructing the Siberian Khanate
}

\author{
Azat S. Salmanov ${ }^{1}$
}

${ }^{1}$ Institute of History, Language and Literature of the Ufa Federal Research Centre of the RAS (71, Oktyabrya Ave., Ufa 450054, Russian Federation)

Cand. Sc. (History), Research Associate

0000-0003-4410-5392. E-mail: azat-salmanov@ mail.ru

(C) KalmSC RAS, 2021

(C) Salmanov A. S., 2021

\begin{abstract}
Introduction. As is commonly believed in Russian historiography, the late $16^{\text {th }}$ century witnessed a final collapse of the Siberian Khanate. However, that event was long followed by repeated attempts from ex-owners of Siberian Yurt - the Kuchumovichs (children and grandchildren of the Siberian Khan Kuchum) - to regain their power. In achieving their goal, they relied on Bashkir and Kalmyk leaders. The ideological supporters of Kuchum's descendants were the Siberian Tatars and Bashkirs, primarily Bashkir Tabyns who also sought a restoration of the Siberian Khanate. But in historical science the question of Bashkirs' participation in the Kuchumovichs' cause to regain Siberian Yurt remains unaddressed. Goals. The study aims at examining the $17^{\text {th }}$ century ethnopolitical history of the Trans-Ural Bashkirs through the prism of the movement attended by the Kuchumovichs, Kalmyks and Dzungars who came up with the idea of reviving the Siberian Khanate. Materials and Methods. The work employs materials already introduced into scientific discourse which, however, were not considered through the prism of Bashkirs' participation in the general movement of nomadic leaders to have struggled for the restoration of the Siberian Khanate. Coupled with the use of historical research methods (historical, comparative and systemic ones), this made it possible to reveal that in the territory of Bashkiria the actions of Bashkir rebels were associated with the policy of the Kuchumovichs and Kalmyk taishas who tried to unite Bashkirs and inhabitants of Western Siberia to withdraw from subordination to the Moscow Government. Thus, the scientific novelty is that the $17^{\text {th }}$ century anti-Russian movement of Bashkirs is being first considered in the context of attempts to restore the Siberian Khanate. Results. Analysis of historical events (departure of Kuchum's grandson Kuchuk to the Karakalpaks and adoption of Russian citizenship by the Kalmyk ruler Ayuka) shows that the rebellious Bashkirs experienced a collapse of hopes for the restoration of the Siberian Khanate, the latter viewed as an opportunity to gain independence from the Tsardom of Russia. Conclusions. Bashkir uprisings of the mid-to-late $17^{\text {th }}$ century should be considered in line with the political situation that had developed in the southeastern outskirts of Russia due to the joint activities of the Kuchumovichs, Kalmyk and Bashkir leaders.

Keywords: Bashkirs, Kalmyks, Kuchumovichs, Siberian Khanate, Bashkiria, Southern Trans-Urals. ethnopolitical history

Acknowledgements. The reported study was funded by government subsidy — project name 'Turkic Peoples of the Southern Urals: Spiritual Culture' (state reg. no. AAAA-A17-117040350082-3).

For citation: Salmanov A. S. Kuchum's Descendants and the Bashkirs: Attempts of Reconstructing the Siberian Khanate. Oriental Studies. 2021. Vol. 14 (2): 238-247. (In Russ.). DOI: 10.22162/26190990-2021-54-2-238-247
\end{abstract}




\section{ठ}

\section{Введение}

В начале XVII в. на сибирских границах Московского государства «все более ощущалось соседство калмыков» [Трепавлов 2018: 78]. В XVI в. в Западной Монголии среди ойратов начались смуты, из-за которых два этнополитических объединения (торгуты и дербеты) откочевали в северо-западном направлении. По Н. В. Устюгову, в Северном Казахстане указанные племена заключили союз с Кучумовичами и стали совершать вместе с ними грабительские набеги на русские границы [Устюгов 1974: 233].

В конце XVI в. к окрестностям Тары переходят 200 тыс. торгутов и дербетов, а уже в 1607 г. сын Кучума Али с отрядом калмыков напал на Уфу. Появление калмыков в Западной Сибири и на Южном Урале не было случайностью. Кучум после своего поражения женил своего сына Ишима на дочери предводителя торгутов Хо-Урлюка, а затем Ишим взял в жены дочь джунгарского Каракулы и сестру предводителя хошутов Байбагиша. Приводя мнение известных историков о завоевательных целях калмыков на запад, где до этого правили потомки Чингисхана, С. У. Таймасов высказывает интересную мысль, что Кучумовичи выступили инициаторами ойратского нашествия. Это мнение косвенно подтверждается тем, что впоследствии на протяжении долгого времени в западной части Великой степи джунгарские правители пытались поставить ханами именно Кучумовичей, в том числе над самими калмыцкими тайшами [Таймасов 2009: 101-103].

В. Т. Тепкеев отмечает, что появление у южных границ Сибири ойратов оживило враждебную деятельность «кучюмлян» [Тепкеев 2015: 47]. В связи с этим необходимо рассмотреть изменение политической обстановки в башкирском Зауралье в контексте деятельности Кучумовичей и калмыцких тайшей.

\section{Материалы и методы}

Методологическую основу исследования составила система принципов, подходов и методов исторической науки. Прин- цип объективности использовался при анализе источников. Системный подход позволил рассмотреть процесс антиколониального движения башкир второй половины XVII в. как целостное явление. Объективность полученных выводов создавалась благодаря изучению и сопоставлению различных источников, мнений и гипотез, при этом максимально избегая односторонней оценки анализируемых событий и явлений. Для решения поставленных задач были использованы как общенаучные методы (анализ, синтез, описание, сравнение и другие), так и специальные исторические методы (описательный, историко-генетический, проблемно-хронологический, синхронный, сравнительно-исторический и другие).

Основу источниковой базы составили сведения Г. Ф. Миллера, В. М. Черемшанского и материалы, составленные А. П. Чулошниковым [Черемшанский 1859; Миллер 2000; Материалы по истории 1936], междисциплинарный подход в работе с которыми позволил рассмотреть проблему башкирских выступлений XVII в. в контексте истории попыток Кучумовичей воссоздать Сибирское ханство.

Появление ойратов в юго-восточной части России и связанные с этим выступления башкир в XVII в.

Приход ойратов в Западную Сибирь и начало движения Кучумовичей за восстановление Сибирского ханства

После пленения Али его заменил Ишим, который стал больше опираться на ойратов, чем на ногайцев, однако окружавшие его войска по Тоболу полностью состояли из табынцев. Царевича Ишима, как и других Кучумовичей, поддерживали Шибаниды Астраханской династии Мавераннахра [Baлиди Тоган 2010: 46]

По мнению Р. Г. Букановой, приход калмыков осложнил военно-политическую обстановку на юго-восточных рубежах России. Кучумовичи, заключившие союз с ойратами, стали нападать на российские окраины [Буканова 2010: 158].

Народы Западной Сибири также решили воспользоваться появлением новой воен- 
но-политической силы. Например, рассчитывая на помощь ойратов, вогуль, остяки и татары в 1609 г. хотели разрушить Тюмень. Но «злоумышленники» были раскрыты (из-за измены остяков), и главные из бунтовщиков казнены [Словцов 2014: 67]. Видимо, из-за неудачной попытки восстания сибирских народов в том же году в городке Таре предводитель торгутов тайша Хо-Урлюк принес присягу на подданство России [Джунджузов 2014: 68].

Предводители ойратов опасались открыто обострять отношения с Русским государством, предпочитая действовать исподтишка. Так, в конце $20-x$ гг. XVII в. в Западной и Южной Сибири прошла серия вооруженных выступлений, организованных ойратами и Кучумовичами с вовлечением местных феодалов [Потапов 1969: 95].

В 1616 г. ойраты атаковали Тару, Томск, Тобольск, Тюмень и другие русские селения [Таймасов 2009: 103].

В период с 1610-1634 гг. группы из кочевых народов (ойраты, телеуты, «ногаи», 〈киргизы» и др.) совершали грабительские набеги на Томский, Тюменский и Тарский округа. Фактически русские гарнизоны оказались бессильны обеспечить контроль над южной частью Западной Сибири. По этому поводу П. А. Словцов задавался вопросом: «кого следует больше обвинять за бедствовавшую границу, самих себя или неприятелей?) [Словцов 2014: 81].

\section{Баикирские восстания в русле движе- ния Кучумовичей \\ В связи с тяжелым положением в Запад-} ной Сибири и в Зауралье Московское правительство начало терять Южное Зауралье, вскоре под ударом кочевых групп оказался уже и Южный Урал. В этой обстановке в 1635 г. российские власти решили окончательно «прибрать к рукам» «центральных башкир». Царское правительство поспешило захватить и северо-восточных башкир. Оно, «подчинив» себе роды Сибирской дороги (коисо, бала-катай, салжиут, кара-табын и ай), намеревалось переселить их из Зауралья в Приуралье. Однако внук Кучума и сын Ишима Аблай отрезал им

${ }^{1}$ В XVII-XVIII вв. Башкирия делилась на 4 административно-территориальные области, которые назывались «дорогами» (от монгольского «даруга»): Казанская дорога, Осинская дорога, Сибирская дорога и Ногайская дорога. путь переселения на запад. Уничтожив сторонников русских, он способствовал началу всеобщего восстания, в том числе и там, где до этого установилась власть российской администрации [Валиди Тоган 2010: 59].

До этого (в 1628-1631 гг.) Аблай в Тарском уезде возглавил восстание сибирских татар, объявив о намерении восстановить Сибирское ханство. В 1632 г. он переходит к Тоболу и Яику, планируя напасть на Уфу [Таймасов 2009: 103].

В 1635 г. султан Аблай, объединившись c калмыками, совершил стремительный рейд на Уфу, вырезав биев, находившихся в связи с русскими. Так, Кучумовичи мстили роду «салжаута» Шугура Кокузова по причине того, что последний, будучи противником Шибанидов, в конце XV в. переселился из Зауралья «поближе к новой русской крепости», где получил земли от российской власти [Азнабаев 2016: 276-279].

В 1635 г. Аблая разгромил отряд Федора Каловского, в рядах которого были и башкиры. Аблай с братом Тевеккелем попали в плен [Таймасов 2009: 103]. Это событие, по мнению А.-3. Валиди Тогана, оказало «удручающее духовное воздействие на сознание табынских, минских и юрматинских башкир, боровшихся против русских» [Baлиди Тоган 2010: 47].

По мнению М. К. Любавского, калмыки оспаривали у России владычество над «ногайскими» и «сибирскими» башкирами [Любавский 1996: 492].

Ойраты притязали на право сбора ясака с племен катай и сынрян (из числа зауральских башкир). В 1623 г. тайша Уруслан требовал ясак с башкир Катайской волости, аргументируя это тем, что раньше катайц̧ы платили ясак ногайцам [Миллер 2000: 341]. Это было связано с тем, что ногайские мурзы, потерпев от ойратов несколько крупных поражений, передали калмыцким тайшам право сбора ясака с башкир [Буляков 2012: 136].

Однако нет данных, свидетельствующих о притязании калмыков на объединение табын. Тот же Уруслан признавал $m a-$ бынцев подданными сибирских царевичей. По его словам, сын Кучума Ишим «пошол в Уфимские волости старых своих людей табынцов сыскивати» [Миллер 2000: 342].

Известно, что от северо-восточных и зауральских башкир, оказавшихся «в зоне политического влияния Сибирского ханства», 
не было никакого волеизъявления о добровольном вхождении в состав Российской империи [Асфандияров 2006: 24]. А это может говорить об отсутствии притязания на них ойратских тайшей для сбора ясака.

По имеющимся данным, башкирское Зауралье для ойратов являлось территорией Кучумовичей. В 1635 г. джунгары, как наиболее могущественная сила в Дешт-и-Кипчаке, признавали за внуком Кучума Давлет-Гиреем «свои земли». В. В. Трепавлов считает, что эти земли царевича находились по берегам Ишима и Тургая. Однако исследователь ссылается на период 40-50 гг. XVII в., в то время как в другом месте он пишет, что Давлет-Гирей в 30-е гг. XVII в. жил с кем-нибудь из тайшей в верховьях Ишима или в озерном краю между Тоболом и Миассом [Трепавлов 2018: 102-105], то есть на территории кочевания восточных табынцев. По мнению В. В. Трепавлова, «северо-восточной границей Ногайской Башкирии служил восточный рубеж Катайской волости Сибирской даруги» [Трепавлов 1997: 6]. Поэтому ойраты, захватившие Ногайскую Орду, смотрели на катайцев как на своих данников, которые «беззаконно» приняли российское подданство, за что стали объектом для нападений [Азнабаев 2016 280].

Из этого следует, что в первой половине XVII в. зауральские башкиры оставались под властью Кучумовичей. Очевидно, что разделение башкир в XVII в. между тремя политическими силами (русскими, калмыками и Кучумовичами) совпадает с границами бывших наследников Улуса Джучи Ногайской Орды, Казанского и Сибирского ханств.

Таким образом, влияние русской администрации в Южном Зауралье, где кочевали башкиры Сибирской дороги, стало заметно ослабевать в связи с приходом калмыков. При этом притязания калмыцких тайшей, сменивших ногайских мурз, распространялись только на башкир Ногайской дороги. Именно поэтому ойраты утвердились на землях тех башкир, которые некогда входили в состав Ногайской орды - в лучших степных землях Уфимского уезда по долинам рек Яик, Орь, Илек, Кизил и Сакмара [Буляков 2012: 135].

Идея восстановления Сибирского ханства исходила главным образом от Кучумо- вичей, мечтавших организовать всеобщее восстание народов. В этом движении Давлет-Гирей надеялся на помощь калмыков, башкир и сибирских татар, а также к выступлению готовились остяки (ханты), вогуль (манси) и самоеды (ненцы). Так, народы Западной Сибири объединились вокруг цели вернуть строй «как было при Кучум царе» [Таймасов 2009: 106].

В связи с удачным отражением притязаний ойратов на башкирские земли, как пишет Б. А. Азнабаев, военная организация башкир показала, что они могли то, что было не под силу уфимским и сибирским воеводам в течение всего XVII в. По мнению исследователя, на этой волне башкиры в 1662-1664 гг. намеревались восстановить Сибирское ханство [Азнабаев 2005: 107]. Башкиры, особенно зауральские, входили в число приверженцев Кучумовичей. В первую очередь отличились башкирские табынцы, активно участвовавшие в борьбе Кучумовичей за возвращение своей власти в Сибирском юрте. Однако сальюты и и $\mathrm{ka}$ maйцы оставались сторонниками российской власти: в 1662 г. они взяли в плен сына Аблая, Кансуяра, с женой и детьми и отправили их в Уфу [Азнабаев 2016: 280].

Известно, что после смерти Давлет-Гирея в начале 1660-х гг. во главе Кучумова клана встал сын Аблая Кучук, который играл, если не организующую, то символическую роль командования военной кампанией в башкирском восстании 1662-1664 гг. Повстанцы про него говорили: «Поднялся на Русь наш царь!). Посланный из Тобольска отряд полковника Д. И. Полуэктова разбил повстанцев. В 1663 г. Кучук и возглавляемые Арсланбеком Баккиным башкиры выиграли сражение с полковником, где он получил три ранения. Но в 1664 г. излечившийся Полуэктов напал на восставших башкир в верховьях Миасса, где погиб Баккин. Кучумовичи, кочевавшие в то время в верховьях Уя в Каратабынской волости, узнав об этом, откочевали к Яику [Трепавлов 2018: 111, 115].

Официальной причиной возмущения башкир, переросшего в первое башкирское восстание, была кампания российских властей по изъятию у башкир и возвращению на родину пленных ойратов. Однако на самом деле за этим восстанием стояли два организующих центра: с одной стороны, 
Кучумовичи Кучук и Абугай (сын Ишима), с другой — «торгутские» тайши Дайчин и Аюка. Башкиры Ногайской дороги ориентировались на калмыцких тайшей, а башкиры Сибирской дороги, особенно зауральские, отдавали свое предпочтение Кучумовичам [Трепавлов 2018: 113, 115]. На царевича Кучука, правнука Кучума, в 1663 г. также ориентировались и башкиры Казанской дороги [Материалы по истории 1936: 168], то есть северо-западные башкиры.

Итак, обнаруживается разделение башкир по политическим предпочтениям, а также региональному фактору. Б. А. Азнабаев для того периода выделяет две группы башкир: «лесные» (Осинская и Сибирская дороги) и «степные» (Ногайская и Казанская дорога), между которыми наблюдалось традиционное соперничество. «Лесные» башкиры отличались тем, что среди них было больше людей, ведущих оседлый образ жизни. «Степные» башкиры имели открытую границу с ойратами. Такие различия существенно влияли на политические интересы этих двух групп [Азнабаев 2015: 96].

Сами башкиры считали, что причиной восстания стало то, что власти взяли в заложники 50 «лучших людей», посадив их под арест в Казани, в связи с отказом башкир идти на войну против Польши и Крыма [Тепкеев 2014: 341].

В. В. Трепавлов приводит слова анонимного немецкого автора, который про башкир 1666 г. писал: «Эти люди показали себя враждебными по отношению к русским, так как Сибирь принадлежала [некогда] предкам... царевича; прежде этих людей он всегда употреблял для своей службы... В настоящее время они враждуют с русскими, и это продолжается с давних пор») [Трепавлов 2018: 112].

Б. А. Азнабаев отмечает, что сопротивление «лесных» башкир приняло наиболее ожесточенный и длительный характер: они продолжили борьбу даже после принесения повинной «степными» башкирами [Азнабаев 2015: 97]. Известно, что уфимский воевода А. Волконский написал письмо «северным» башкирам (Сибирская и Осинская дороги), в котором он информировал их о заключении мира с «южными и западными») башкирами. Б. Э. Нольде, ссылаясь на пере- писку сибирских властей в 1667 г., пишет, что северо-восточные племена башкир долгое время не подчинялись русским. Москва смогла их подчинить лишь с помощью военной силы [Нольде 2013: 328].

Во времена башкирского восстания 1662-1664 гг. башкиры Ногайской и Осинской дорог существенно пополнили ряды отряда Кучука. Своим приверженцам из башкирских предводителей Кучук выдавал ярлыки, что можно относить к позднему пережитку джучидской канцелярской и инвеститурной практики. К 1667 г. Кучук смог из (татаро-башкиро-калмыцкого» окружения сплотить вокруг себя преданных соратников, провозгласивших его ханом. Поэтому в 1668 г. хошутский тайша Цаган заявлял русским: «Кучук-хан не нашего де улусу», то есть фактически признавал его независимость. В тот период он в своей грамоте обозначается как «Кучук Бахадур-хан». Объединенные Кучуком башкиры и ойраты вместе фигурируют в источниках, когда они в конце 1660-х гг. участвовали в набегах на ясачных плательщиков в Сибири. В. В. Трепавлов пишет, что, как и раньше, «ворами» и «изменниками» были в основном башкирские табынцы [Трепавлов 2018: 117-125]

Однако ключевой опорой Кучумовичей все же являлись ойратские объединения, которые постепенно из Западной Сибири и Казахстана перемещались на Волгу. Откочевал на юго-запад во главе 50 тыс. кибиток и давний союзник Кучумовичей - торгутский Хо-Урлюк с сыновьями, одним из которых был Дайчин [Трепавлов 2018: 126,

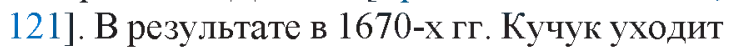
к каракалпакам вместе с башкирами (около 200 «дымов») «Салжеутского, Барын-Табынского, Шуранского и Кипчакского» родов [Таймасов 2009: 108].

По С. И. Хамидуллину, после завершения башкирского восстания 1662-1664 гг. Кучук-хан стал правителем каракалпаков [Хамидуллин 2017: 74].

В 1696 г. тобольский казак В. Кобяков слышал от казахов о наличии у каракалпаков башкир, ушедших вместе с Кучуком [Трепавлов 2018: 129]. Кучук в истории башкир сыграл важную роль «природного» хана. Неслучайно он В. Т. Тепкеевым причислен к башкирам [Тепкеев 2014: 424]. 


\section{Калмьцкий фактор в башкирских вос- станиях}

После ухода Кучука башкиры продолжали вести борьбу. Б. Э. Нольде указывает, что в 1675 г. волнения северо-восточных башкир «привели к крупному восстанию» [Нольде 2013: 329].

Восставшие башкиры в 1676 г. вновь объединились с калмыками из владения Аюки, а также с казахами. Башкиры под предводительством Сеита напали на Закамскую линию, разорив города и крепости, вторглись в Казанский уезд. Примечательно, что пленных они отсылали для продажи в Джунгарию [Казанцев 1866: 8]. В. М. Черемшанский пишет, что башкиры, объединившись с калмыцкими тайшами и подвластными им ногайцами, разоряли селения в Уфимском и Казанском уездах [Черемшанский 1859: 3].

В этом восстании с 1677 г. «борьбу табынцев возглавил тархан Ишмухамет». По мнению Б. Э. Нольде, восстание башкир происходило в 1676-1682 гг., после которого в Башкирии на долгое время установился мир [Нольде 2013: 329]. В этот период (в 1675-1676 и 1681-1683 гг.) отмечается серия калмыцких набегов на русские территории и населенные пункты. Калмыки действовали как самостоятельно, так и в союзе с башкирами [Васильев 2020: 176].

В 1683 г. к оз. Чебаркуль подошел Кучумович Хасан (сын Аблая) с калмыцкой конницей. В. В. Трепавлов отмечает, что неизвестно, с какой целью пришел Хасан с калмыками, но башкиры «укрылись в лесах и горах〉 и не пошли за ним. Причиной завершения башкирского восстания в 1684 г., очевидно, явилось то, что в тот год калмыцкий тайша Аюка, готовивший весенний удар «на Уфинской и сибирских городов на уезды» 40-тысячной армией под руководством внука Ишима Дюдюбака, вдруг неожиданно принял российское подданство, в связи с чем этот поход не состоялся [Трепавлов 2018: 128].

В то же время известно, что башкирское восстание 1681-1684 гг. нашло поддержку со стороны калмыков. Как отмечает И. Г. Акманов, в тот период для башкир была важна поддержка со стороны калмыцких отрядов [Акманов 2016: 124]. А. Г. Митиров пишет, что Аюка со своими братьями, объединившись с башкирами, (хходил) на российские города в Казанский и Уфимский уезды [Митиров 1998: 101].

Аюка как выдающийся полководец и искусный дипломат неоднократно давал клятву верности российскому правительству, но при первой возможности нарушал их. Поэтому неудивительно, что в 1681 и 1683 гг. он с восставшими башкирами участвовал в разгроме русских и черемисских сел в Казанском и Уфимском уездах и на Волге [Джунджузов 2014: 70]. Так, Аюка и другие тайши приняли участие в башкирском восстании 1681-1683 гг., однако уже в 1683 г. он не столько поддерживал башкир, сколько пытался их подчинить [Ремилева 2010: 226].

В этой связи показателен пример казахско-джунгарских взаимоотношений. По мнению С. А. Едилхановой, Джунгария вела политику недопущения вхождения казахских жузов в состав России [Едилханова 2005: 146].

То же самое можно сказать и про политику Джунгарии в отношении башкир, так как указанный выше Дюдюбак был поставлен главой над калмыцкими тайшами именно джунгарским правителем Галданом Бошокту-ханом, который направил Кучумовича «на старинные ево кочевья по Ишиму реке, где кочевали дед и отец ево» с поручением начать военные действия против башкир [Трепавлов 2018: 127].

Галдан Бошокту-хан хотел держать под контролем калмыцких тайшей, сконцентрировав власть в руках Кучумовича Дюдюбака. Однако Аюка, дабы избежать зависимости от Джунгарии, выбрал подданство русскому царю, видя в этом временное решение своих проблем. Позднее, в 1690 г., это не помешало Аюке получить ханский титул от Далай-ламы [Джунджузов 2014: 68]. Со своей стороны царское правительство помогло Аюке сосредоточить власть в своих руках, чтобы решать свои проблемы на юго-восточных границах с помощью сильного централизованного ханства [Кундакбаева 2015: 183].

\section{Заключение}

Нежелание башкир продолжить борьбу за создание «своего» государства, очевидно, главным образом было связано с потерей союзника в лице калмыков. Известно, что после принятия Аюкой российского подданства отношения между калмыка- 
ми и башкирами вновь ухудшились, и это привело к взаимным набегам. Например, по источникам, в 1692 г. улус Аюки активно готовился к нападению башкир [Батмаев 1993: 123]. А в 1708 г. Аюка принимал участие в подавлении очередного башкирского восстания [Митиров 1998: 109], что позволило российским властям ограничить масштабы народного движения и воспрепятствовать установлению контактов башкир с булавинцами [Азнабаев 2015: 86]. К этому можно добавить: лишь в середине XVIII в.

\section{Литература}

Азнабаев 2005 - Азнабаев Б. А. Интеграция Башкирии в административную структуру Российского государства (вторая половина XVI - первая треть XVIII вв.). Уфа: БашГУ, 2005. $230 \mathrm{c}$.

Азнабаев 2015 - Азнабаев Б. А. Возобновление российского подданства башкир в 1722 г. // Кочевые народы Центральной Евразии XVIII-XIX вв.: сравнительно-исторический анализ политики Российской империи: сб. ст. Алматы: Казахский университет, 2015. C. $85-101$

Азнабаев 2016 - Азнабаев Б. А. Башкирское общество в XVII - первой трети XVIII в. Уфа: БашГУ, 2016. 368 с

Акманов 2016 - Акианов И. Г. Башкирские восстания XVII-XVIII вв. - феномен в истории народов Евразии. Уфа: Китап, 2016. 376 с.

Асфандияров 2006 - Асфандияров А. З. Башкирия после вхождения в состав России (вторая половина XVI - первая половина XIX в.). Уфа: Китап, 2006. 504 c.

Батмаев 1993 - Батмиев M. М. Калмыки в XVII-XVIII веках. События, люди, быт: в 2-х книгах. Элиста: Калмкнигоиздат, 1993. $381 \mathrm{c}$.

Буканова 2010 - Буканова Р. Г. Города-крепости на территории Башкортостана в XVIXVII вв. Уфа: Китап, 2010. 264 с.

Буляков 2012 - Буляков И. И. Золотоордынскис государственные традиции в управлении башкирским краем во второй половине XVI - первой трети XVII в. Уфа: ИИЯЛ УНЦ PAH, 2012. $180 \mathrm{c}$.

Валиди Тоган 2010 - Валиди Тоган А.-3. История башкир. Уфа: Китап, 2010. $352 \mathrm{c}$.

Васильев 2020 - Васильев Д. В. Рождение империи. Юго-восток России: XVIII - первая половина XIX в. СПб.: Дмитрий Буланин, 2020.608 c. была возведена Самарская укрепленная линия для пресечения взаимных набегов башкир и калмыков [Колесник 1997: 12].

Таким образом, попытки воссоздания Сибирского ханства во многом были связаны с политикой калмыцких тайшей, зачастую поддерживавших Кучумовичей и башкир в их выступлениях против Русского государства. Идея возвращения к жизни Сибирского ханства была подавлена уходом Кучука к каракалпакам и принятием Аюкой российского подданства.

Джунджузов 2014 - Джсунджсузов С. В. Калмыки в Среднем Поволжье и на Южном Урале: имперские механизмы аккультурации и проблема сохранения этнической идентичности (середина 30-х годов XVIII - первая четверть XX века): монография. Оренбург: ОГАУ, 2014. $434 \mathrm{c}$.

Едилханова 2005 - Едилханова С. А. Казахско-джунгарские взаимоотношения в XVIIXVIII веках (некоторые историографические аспекты проблемы). Алматы: ДайкПресc, 2005. $162 \mathrm{c}$.

Казанцев 1866 - Казамцев И. М Описание башкирцев, составленное Н. Казанцевым. СПб.: Оо̆щественная польза, $1866.97 \mathrm{c}$.

Колесник 1997 - Колесник В. И. Демографическая история калмыков в XVII-XIX вв.: уч. пособ. Элиста: КалмГУ, 1997. 135 с.

Кундакбаева 2015 - Кундакбаева Ж. Б. От военно-административного надзора к имперской бюрократической системе управления: методы включения калмыков в административно-политическую систему Российской империи в XVIII веке // Кочевые народы Центральной Евразии XVIII-XIX вв.: сравнительно-исторический анализ политики Российской империи: сб. ст. Алматы: Казахский университет, 2015. С. 179-198.

Любавский 1996 - Любавский М. К. Обзор истории русской колонизации с древнейших времен и до ХХ века. М.: изд-во МГУ, 1996. $688 \mathrm{c}$.

Материалы по истории 1936 - Материалы по истории Башкирской АССР. Ч. 1 / отв. ред. А. П. Чулошников. М.; Л.: АН СССР, 1936. $631 \mathrm{c}$.

Миллер $2000-$ Миллер Г. Ф. История Сибири: в 3 т. Т. 2. М.: Вост. лит., 2000. 796 с.

Митиров 1998 - Митиров А. Г. Ойраты-калмыки: века и поколения. Элиста: Калмкнигоиздат, 1998.384 с. 
Нольде 2013 - Нольде Б. Э. История формирования Российской империи. СПб.: Дмитрий Буланин, 2013. $848 \mathrm{c}$

Потапов 1969 - Потапов Л. П. Этнический состав и происхождение алтайцев. Историко-этнографический очерк. Л.: Наука, 1969. $196 \mathrm{c}$.

Ремилева 2010 - Ремилева E. С. Ойрат-монголы. Обзор истории европейских калмыков (Elena Remileva. Oirat-Mongolen. Ein Überblick über die Geschichte der europäischen Kalmücken). Weiler: Bertugan, 2010.690 c.

Словцов 2014 - Словцов П. А. История Сибири. От Ермака до Екатерины II. М.: Вече, 2014. $512 \mathrm{c}$

Таймасов 2009 - Таймасов С. У. Башкирско-казахские отношения в XVIII веке. М.: Наука, $2009.344 \mathrm{c}$.

Тепкеев 2014 - Тепкеев В. T. Калмыки в Северном Прикаспии во второй трети XVII века: проблемы политических взаимоотношений. Элиста: Джангар, 2014. 448 с.

\section{References}

Aznabaev B. A. Integracija Bashkirii v administrativnuju strukturu Rossijskogo gosudarstva (vtoraja polovina 16 - pervaja tret' $18 \mathrm{vv}$.) [Integration of Bashkiria into the administrative structure of the Russian state (second half of the $16^{\text {th }}$ - first third of the $18^{\text {th }}$ centuries)]. Ufa: Bashkir State University, 2005. 230 p. (In Russ.)

Aznabaev B. A. Renewal of Russian citizenship to the Bashkirs in 1722. Kochevye narody Central'noj Evrazii 18-19 vv.: sravnitel'no-istoricheskij analiz politiki Rossijskoj imperii: sbornik statej. Almaty: Kazakh University. 2015. Pp. 85-101. (In Russ.)

Aznabaev B. A. Bashkirskoe obshhestvo v 17 - pervoj treti $18 \mathrm{v}$. [Bashkir society in the $17^{\text {th }}-$ first third of the $18^{\text {th }}$ century]. Ufa: Bashkir State University, 2016. 368 p. (In Russ.)

Akmanov I. G. Bashkirskie vosstanija 17-18 vv. fenomen $v$ istorii narodov Evrazii [Bashkir uprisings of the $17^{\text {th }}-18^{\text {th }}$ centuries - a phenomenon in the history of the peoples of Eurasia]. Ufa: Kitap, 2016. 376 p. (In Russ.)

Asfandijarov A. Z. Bashkirija posle vhozhdenija v sostav Rossii (vtoraja polovina 16 - pervaja polovina 19 v.) [Bashkiria after joining Russia (second half of the $16^{\text {th }}-$ first half of the $19^{\text {th }}$ century)]. Ufa: Kitap, 2006. 504 p. (In Russ.)

Batmaev M. M. Kalmyki v 17-18 vekah. Sobytija, ljudi, byt: v 2-h knigah [Kalmyks in the $17^{\text {th }}$ $-18^{\text {th }}$ centuries. Events, people, everyday life:
Тепкеев 2015 - Тепкеев B. T. Ойраты в начале XVII века. Элиста: КИГИ РАН, 2015. 198 с.

Трепавлов 1997 - трепавлов В. В. Ногаи в Башкирии, XV-XVII вв. // Материалы и исследования по истории и этнологии Башкортостана. Уфа: Урал. науч. центр РАН, 1997. № 2. C. 5-37.

Трепавлов 2018 - Трепавлов В. В. Кучумовичи в Сибири: борьба за реванш // Сибирские царевичи в истории России / В. В. Трепавлов, А. В. Беляков. СПб.: Изд-во Олега Абышко, 2018. C. 13-162.

Устюгов $1974-$ Устюгов Н. В. Научное наследие. М.: Наука, 1974. 254 с.

Хамидуллин 2017 - Хамидуллин С. Н. Очерк истории башкир рода Табын // История башкирских родов. Табын. Т. 28. Ч. 1. Уфа: ИИЯЛ УНЦ РАН; Китап, 2017. С. 17-122.

Черемшанский 1859 - Черемианский $B . M$. Описание Оренбургской губернии в хозяйственно-статистическом, этнографическом и промышленном отношениях. Уфа: Тип. Оренбург. губ. правления, 1859. 472 с.

in 2 books]. Elista: Kalmyk Book Publ., 1993. 381 p. (In Russ.)

Bukanova R. G. Goroda-kreposti na territorii Bashkortostana v 16-17 vv. [Fortress cities on the territory of Bashkortostan in the $16^{\text {th }}-17^{\text {th }}$ centuries]. Ufa: Kitap, 2010. 264 p. (In Russ.)

Buljakov I. I. Zolotoordynskie gosudarstvennye tradicii $\mathrm{v}$ upravlenii bashkirskim kraem vo vtoroj polovine 16 - pervoj treti $17 \mathrm{v}$. [Golden Horde state traditions in the management of the Bashkir region in the second half of the $16^{\text {th }}-$ first third of the $17^{\text {th }}$ century]. Ufa: IHLL USC RAS, 2012. 180 p. (In Russ.)

Validi Togan A.-Z. Istorija Bashkir [Bashkir history]. Ufa: Kitap, 2010. 352 p. (In Russ.)

Vasil'ev D. V. Rozhdenie imperii. Jugo-vostok Rossii: 18 - pervaja polovina $19 \mathrm{v}$. [The birth of an empire. Southeast of Russia: $18^{\text {th }}-$ first half of $19^{\text {th }}$ century]. St. Petersburg: Dmitrij Bulanin, 2020. 608 p. (In Russ.)

Dzhundzhuzov S. V. Kalmyki v Srednem Povolzh'e i na Juzhnom Urale: imperskie mehanizmy akkul'turacii i problema sohranenija jetnicheskoj identichnosti (seredina 30 -h godov 18 - pervaja chetvert' 20 veka): monografija [Kalmyks in the Middle Volga Region and the Southern Urals: Imperial Mechanisms of Acculturation and the Problem of Preserving Ethnic Identity (mid-1830s - first quarter of the $20^{\text {th }}$ century): monograph]. Orenburg: Orenburg State Agrarian University, 2014. 434 p. (In Russ.) 
Edilhanova S. A. Kazahsko-dzhungarskie vzaimootnoshenija v XVII-XVIII vekah (nekotorye istoriograficheskie aspekty problemy) [Kazakh-Dzhungar relations in the $17^{\text {th }}-18^{\text {th }}$ centuries (some historiographic aspects of the problem)]. Almaty: Dajk-Press, 2005. 162 p. (In Russ.)

Kazancev I. M. Opisanie bashkircev, sostavlennoe N. Kazancevym [Description of the Bashkirians, compiled by N. Kazantsev]. St. Petersburg: Public benefit, 1866. 97 p. (In Russ.)

Kolesnik V. I. Demograficheskaja istorija kalmykov v 17-19 vv. [Demographic history of Kalmyks in the $17^{\text {th }}-19^{\text {th }}$ centuries]. Elista: Kalmyk State University, 1997. 135 p. (In Russ.)

Kundakbaeva $Z$ h. B. From military-administrative oversight to an imperial bureaucratic management system: methods of including Kalmyks in the administrative-political system of the Russian Empire in the $18^{\text {th }}$ century. Kochevye narody Central'noj Evrazii 18-19 vv.: sravnitel'no-istoricheskij analiz politiki Rossijskoj imperii: sbornik statej. Almaty: Kazakh University, 2015. Pp. 179-198. (In Russ.)

Ljubavskij M.K. Obzor istorii russkoj kolonizacii s drevnejshih vremen i do XX veka [Review of the history of Russian colonization from ancient times to the $20^{\text {th }}$ century]. Moscow, 1996. 688 p. (In Russ.)

Materials on the history of the Bashkir ASSR Part 1. Executive editor A.P. Chuloshnikov. Moscow - Leningrad: USSR Academy of Sciences, 1936. 631 p. (In Russ.)

Miller G. F. Istorija Sibiri: v 3 t. T. 2. [History of Siberia: in 3 volumes. Vol. 2.]. Moscow: Oriental literature, 2000. 796 p. (In Russ.)

Mitirov A. G. Ojraty - kalmyki: veka i pokolenija [Oirats - Kalmyks: centuries and generations]. Elista: Kalmyk Book Publ., 1998. 384 p. (In Russ.)

Nol'de B. Je. Istorija formirovanija Rossijskoj imperii [The history of the formation of the Russian Empire]. St. Petersburg: Dmitrij Bulavin, 2013. 848 p. (In Russ.)

Potapov L. P. Jetnicheskij sostav i proishozhdenie altajcev. Istoriko-jetnograficheskij ocherk
[Ethnic composition and origin of the Altaians. Historical and ethnographic sketch]. Leningrad: Nauka, 1969. 196 p. (In Russ.)

Remileva E. S. Ojrat-mongoly. Obzor istorii evropejskih kalmykov [Oirat Mongols. Review of the history of European Kalmyks]. Weiler: Bertugan, 2010. 690 p. (In Russ.)

Slovcov P. A. Istorija Sibiri [History of Siberia]. Ot Ermaka do Ekateriny II. Moscow: Veche, 2014. 512 p. (In Russ.)

Tajmasov S. U. Bashkirsko-kazahskie otnoshenija v XVIII veke [Bashkir-Kazakh relations in the $18^{\text {th }}$ century]. Moscow: Nauka, 2009. 344 p. (In Russ.)

Tepkeev V. T. Kalmyki v Severnom Prikaspii vo vtoroj treti 17 veka: problemy politicheskih vzaimootnoshenij [Kalmyks in the Northern Caspian region in the second third of the $17^{\text {th }}$ century: problems of political relations]. Elista: Dzhangar, 2014. 448 p. (In Russ.)

Tepkeev V. T. Ojraty v nachale XVII veka [Oirats at the beginning of the $17^{\text {th }}$ century]. Elista: KIHR RAS, 2015. 198 p. (In Russ.)

Trepavlov V. V. Nogai in Bashkiria, XV-XVII centuries. Materialy $\mathrm{i}$ issledovanija po istorii $\mathrm{i}$ jetnologii Bashkortostana. Ufa, 1997. № 2 . Pp. 5-37. (In Russ.)

Trepavlov V.V. Kuchumovichi in Siberia: fight for revenge. Sibirskie carevichi v istorii Rossii / V. V. Trepavlov, A.V. Beljakov. St. Petersburg: Oleg Abyshko Publ., 2018. Pp. 13-162. (In Russ.)

Ustjugov N. V. Nauchnoe nasledie [Scientific heritage]. Moscow: Nauka, 1974. 254 p. (In Russ.)

Hamidullin S. I. Essay on the history of the Bashkirs of the Tabyn clan. Istorija bashkirskih rodov. Tabyn. T. 28. Ch. 1. Ufa: IHLL USC RAS; Kitap, 2017. Pp. 17-122. (In Russ.)

Cheremshanskij V.M. Opisanie Orenburgskoj gubernii V hozjajstvenno-statisticheskom, jetnograficheskom i promyshlennom otnoshenijah [Description of the Orenburg province in economic, statistical, ethnographic and industrial relations]. Ufa: Printing house of the Orenburg provincial government, 1859. $472 \mathrm{p}$. (In Russ.) 